\title{
IMPACT OF IRRIGATION INTERVALS AND N- LEVELS ON WATER PRODUCTIVITY, GROWTH AND YIELD OF GIZA 179 RICE VARIETY UNDER DRILL- SEEDED METHOD El-Ekhtyar A.M. \\ Rice Research\&Training Center, Sakah, KafrELSheikh, Field crop Research Institute, Agricultural Research Center, Egypt.
}

\begin{abstract}
Two field experiments were conducted at the Farm of Sakha Agricultural Research Station, Sakha,Kafr- ELsheikh, Egypt during 2012 and 2013 summer seasons. The study aimed to find out the proper nitrogen levels of drill seeded rice of Giza179 rice cultivar under prolonged irrigation interval. The experiment was performed in strip-plot design with four replications. The horizontal plots were devoted to three irrigation treatments; continuous flooding (CF) every 3 days, irrigation every 6 and 9 days. The nitrogen levels Viz; 0, 110, 165 and $220 \mathrm{~kg} \mathrm{Nha}^{-1}$ were distributed in the vertical plots. The main results revealed that the growth characteristics as well as grain yield and its attributes were significantly affected by the irrigation intervals in both season of study. flag leaf area, leaf area index,chlorophyll content, plant height, number of tillers $/ \mathrm{m}^{-}{ }^{2}$, number of paniclesm ${ }^{2}$, number of filled grains panicle ${ }^{-1}, 1000-$ grain weight, grain yield tha ${ }^{-1}$ and straw yield tha ${ }^{-1}$ were decreased as irrigation intervals were prolonged up 9 days in the two seasons of study. On the other hand, the period from sowing to heading was prolonged and sterility\% was increased. Harvest index wasn't affected by irrigation intervals in both seasons. Both irrigation intervals of CF and 6 days were at a par regarding rice grain yield of both seasons of study while, panicles number $/ \mathrm{m}^{-2}$ and filled grainspanicle ${ }^{-1}$ showed the same pattern in 2012 season. Water use efficiency was found to be optimum with irrigation interval of 6- days, with water save \% amounted to be 6.93- 5.78..Meanwhile, prolonged irrigation interval up to 9 days gave the highest of water save \%(18.8-19.5\%) and yield reduction. Increasing nitrogen level up to $220 \mathrm{~kg} \mathrm{Nha}^{-1}$ significantly increased all studied traits without significant differences with those produced by $165 \mathrm{~kg} \mathrm{Nha}^{-1}$ in most assessed traits and rice grain yield in both seasons of study. On controversy, sterility\% significantly decreased as nitrogen level was increased up to $165 \mathrm{kgNha}^{-1}$ while beyond the latter level the sterility\% started to slightly increase. Increasing nitrogen level clearly increased water use efficiency. The interaction effect had significant effect on flag leaf area, leaf area index, plant height, number of tillers $\mathrm{m}^{-2}$, number of paniclesm ${ }^{-2}$, filled grains number/panicle, sterility\%, 1000-grain weight, grain and straw yields in both seasons of study. The interaction effect had no significant effect on heading date, chlorophyll content and harvest index in both seasons. The interaction effect came to confirm that the irrigation every 6 days with $165 \mathrm{~kg} \mathrm{Nha}^{-1}$ was being to be effective in increasing water use efficiencies, water save and maintain reasonable grain yield.Under prolonged irrigation interval, increasing nitrogen level could relief the harmful of water stress.

It could be concluded that the nitrogen level of $165 \mathrm{~kg} \mathrm{Nha}^{-1}$ and irrigation every 6-day is relevant for drilled Giza 179 rice variety providing high water use efficiency with high yield and reasonable water save percentage.
\end{abstract}

Keywords: drill seeded rice, irrigation intervals, and Nitrogen levels 


\section{INTRODUCTION}

Irrigated rice crop is increasingly facing water scarcity. More progress has been made for water saving with more rice production.Furthermore, water efficient irrigation regimes for rice have been tested, advanced, applied and distributed in different regions in Egypt, particularly, under newly reclaimed saline soil. Because of continued population growth and economic developments, the demand for fresh water to meet industrial and domestic needs has increased in Egypt. Therefore, it is expected that, in near future, less water will be available for rice growing.Tabbal et al.(2002) reported that reduced water inputs and increased water productively of rice grown just under saturated soil conditions were compared with traditional flooding rice. Khafaga et al.(2006)and Zayed et al.(2007) stated that continuous flooding and watering at 6 days intervals were comparable regarding, rice growth, yield attributing traits and grain yield, but the irrigation interval of 6 days gave the highest value of water use efficiency and water productivity. Moreover, Anbumozhi et al.(1998), EL-Kholy et al.(1999), El Refaee et al.(2005) and Majied. (2012) came to similar results. Khafaga et al.(2006) found that the percolation losses and evapotranspiration (ETa)were increased by increasing ponding water depth

Water and nutrients availability are two major constraints in rice fields in Egypt. Both stresses interact and contribute to low rice productivity. Many Egyptian farmers are shifting rice establishment method from transplanting in puddle soil to direct seeding in either puddle soil or dry soil after dry tillage because the latter requires less labour, time, drudgery and cultivation cost (El-Ekhtyar, 2004and Farooq et al.,2009 and 2011). Direct seeding requires only $34 \%$ of the total labour requirement of transplanted rice (Ho NaiKinandRomli 2002) and 29\% of the total cost of transplanted rice production without any yield loss. Drill seeding, a variant of direct seeding, is sowing the seeds in rows at specified seed rate, depth, and covers those with soil under dry or moist condition. This method of rice establishment substantially reduces labour requirement, improves emergence of seeds, and reduces lodging to less than $10 \%$ (Bakkeret al., 2002).Nitrogen fertilizer management in direct-seeded rice cultivation is important and a challenging task to achieve high yield and increased $\mathrm{N}$ use efficiency (NUE). In general, $\mathrm{N}$ uptake is less than $40 \%$ of the total $\mathrm{N}$ applied in rice cultivation (Ladha et al., 2005). The low level of $\mathrm{N}$ utilization is due to high $\mathrm{N}$ losses through volatilization, denitrification, runoff, and leaching. Application of $\mathrm{N}$ not synchronized with plant need leads to high $\mathrm{N}$ losses, low yield, and poor grain quality. Nitrogen uptake patterns over the growing season depend on the availability of soil $\mathrm{N}$, timing of fertilizer application, and amount of fertilizer $\mathrm{N}$ available (Ladha et al., 2005). Increasing nitrogen rates from 150 - $165 \mathrm{~kg}$ Nha-1 significantly increased rice growth, yield and yield attributing characteristics of drill seeded rice (Ali et al., 2012 and El- HabitHowida et al., 2013). Zayed et al. (2006) found that NUE was higher with low nitrogen levels and was lower with increasing nitrogen level. El-Refaee et al.( 2008) indicated that significant 
amount of irrigation water can be saved was small yield reduction if rice field was irrigated every 6 days using $165 \mathrm{~kg} \mathrm{Nha}^{-1}$.

Information on nitrogen use efficiency(NUE), water use efficiency(WUE) andnitrogen ( $N$ ) balance under intermittent irrigation management approach rice are imperative in making sound fertilizer recommendations that reduce $\mathrm{N}$ losses, save water and maintain potential yield of drill-seeded rice. Research findings on NUE and N balance in paired and single-row planting methods in drill-seeded rice are, however, meager.

This paper presents the results of a field study conducted to evaluate the various irrigation intervals (irrigation intermittent system) and five $\mathrm{N}$ management strategies on crop and water productivity and $\mathrm{N}$ use-efficiency.

\section{MATERIALS AND METHODS}

Two field experiments were conducted at Sakah Agricultural Research Station Farm during summer seasons of 2012 and 2013.Soil texture of the experimental sites is classified as clay soil and its chemical analysis was presented in Table1. New released variety Giza 179 was used in this study. The experiment was laid out in strip plot design with four replications. The horizontal plots were devoted to three irrigation intervals; continuous flooding with irrigating every 3 days (CF), irrigation intervals every 6 and 9 days. Meanwhile nitrogen levels; $0,110,165$ and $220 \mathrm{~kg} \mathrm{~N}$ ha-1 in the form of urea $(46 \%)$ were allocated in the vertical plots. Soil samples were taken before land preparation at the depth of $0-30 \mathrm{~cm}$ from the soil surface.The soil samples were completely mixed, dried and grounded, and then physically and chemicallycharacteristics were analyzed according to Black et al. (1965). Results of analysis in both seasons are shown in Table 1.

Table 1: Physical and chemical analysis of the experimental sites.

\begin{tabular}{|l|c|c|}
\hline Character & $\mathbf{2 0 1 2}$ & $\mathbf{2 0 1 3}$ \\
\hline Physical analysis: & & \\
Sand (\%) & 16.5 & 15.5 \\
Silt (\%) & 28.0 & 30.0 \\
Clay (\%) & 55.5 & 54.5 \\
Soil texture & Clayey & Clayey \\
\hline Chemical analysis: & & \\
E.C. (ds/m) & 1.85 & 1.80 \\
Organic matter (\%) & 1.81 & 1.83 \\
pH & 8.04 & 8.06 \\
\hline Available N (ppm) & 28 & 29 \\
P (ppm) & 14 & 15 \\
K (ppm) & 350 & 360 \\
Fe (ppm) & 4.55 & 5.00 \\
Zn (ppm) & 0.99 & 1.00 \\
\hline
\end{tabular}

The phosphorus and potassium fertilizers were applied in the forms of calcium super phosphate $\left(15.5 \% \mathrm{P}_{2} \mathrm{O}_{5}\right)$ and potassium sulphate $\left(48 \% \mathrm{k}_{2} \mathrm{O}\right)$ in the rates of $37 \mathrm{~kg} \mathrm{P}_{2} \mathrm{O}_{5}$ and $50 \mathrm{k}_{2} \mathrm{Oha}^{-1}$,repectively. Nitrogen in the form of urea $(46.5 \% \mathrm{~N})$ was added into three equal splits, $1 / 3$ at 25,50 and 75 days after sowing at the above nominated levels. The experimental sites were well 
tillage. The seeds of $120 \mathrm{~kg}$ ha- 1 were mechanically drilled at rows of $17 \mathrm{~cm}$ spaces and $1 \mathrm{~cm}$ below soil surface on May, 5 in the two seasons. The weeds were controlled chemically using Saturn $50 \%$ at 7.5 liters ha- 1 into 350 liter waterha-1 and sprayed at four days after drilling. The drilled soil was flashy irrigated every 6 days interval after sowing for 25 days. Zinc fertilizer at the rate of $24 \mathrm{~kg} \mathrm{ZnSO}$ ha-1 was mixed with sand and manually broadcasted at the beginning of flooding. Then, the irrigation treatments were applied as aforementioned. Each Irrigation treatment was tightly surrounded by deep ditches with $2 \mathrm{~m}$ wide and $1 \mathrm{~m}$ depth to isolate each other. The plot size was $15 m^{2}$ ( $3 m$ width* $5 m$ length).

At heading stage, plant samples from area of $0.125 \mathrm{~m}^{2}(0.74 \mathrm{~m}$ length ${ }^{*} 0.17 \mathrm{~m}$ width) from each plot were taken to estimate days to heading, flag leaf area $\left(\mathrm{cm}^{2}\right)$, leaf area index (LAl)) and chlorophyll content (SPAD value)according to Yoshida et al.(1972). Leaf area index is the ratio between the leaf area $\left(\mathrm{cm}^{2}\right)$ of the plant divided by ground area occupied by the plants $\left(\mathrm{cm}^{2}\right)$ and chlorophyll content was estimated by chlorophyll meter (Model Li 3000L)

At harvest, plant of the area of $0.125 \mathrm{~m}^{2}(74 \mathrm{~cm}$ length $\times 17 \mathrm{~cm}$ width) from each plot were counted to determine number of tillers $\mathrm{m}^{2}{ }^{2}$ and number of panicles $\mathrm{m}^{-2}$ and the plant height $(\mathrm{cm})$ was measured. Ten main panicles from each plot were packed to determine number of filled grains panicle ${ }^{-1}$, sterility\% and 1000-grain weight $(\mathrm{g})$.

The plants in the central rows of $10 \mathrm{~m}^{2}$ of each plot were harvested, dried, threshed, then grain and straw yields were determined at $14 \%$ moisture content and converted into $\mathrm{t} \mathrm{ha}^{-1}$ as well as harvest index.

The volume of irrigation water applied in each plot was measured by a calibrated water meter with water pump. The amount water before treatments application (the first 25 days period of drilled rice growth was recorded as well as water required for irrigation treatments of all experiments. Water use efficiency was calculated according to Michael (1978).

All data collected were subjected to standard statistical analysis following the proceeding described by Gomez and Gomez (1984) using the computer program (MSTAT). The treatment means were compared using Duncan's multiple range test Duncan (1955). ${ }^{*}$ and ${ }^{* *}$ symbol used in all Tables indicate the significant at $5 \%$ and $1 \%$ levels of probability, respectively, while, NS means not significant.

\section{RESULTS AND DISCUSSIONS}

\section{Effect of irrigation intervals}

Data furnished in Table 2 revealed that the irrigation intervals significantly influenced the studied growth parameters under such conditions in both seasons. Prolonging irrigation intervals up to nine days severely declined growth of Giza 179 rice variety in 2012 and 2013 seasons, respectively. The intermittent irrigation interval of 6 days slightly affected rice growth. It is clear that the continuous flooding gave the highest means of tested rice growth characteristics, flag leaf area, leaf are index and 
chlorophyll content in both seasons (Table 2). On the other hand, the prolonged irrigation interval of 9 days produced the minimum values of growth parameters in the first and second seasons, respectively. The irrigation every 9 days gave the longest period from sowing to heading. Water stress increased osmotic pressure resulted in high water potential inside plant cells, low water content, low photosynthesis rate and low metabolism process. Furthermore, the water stress might affect cell division and elongation resulted short plants, narrow leaves leading to small leaf area index and flag leaf area. Low water content of leaf induced by water stress might destroy chlorophyll pigments resulted in low chlorophyll content led to low photosynthesis and dry matter production. Water stress might increase antioxidants releasing in plant cell which damaged the cell membranes and the protein shrinking as a result of water imbalance. Under water stress, the respiration rate might be increased resulted in more water and energy losses against anabolism and ultimately induced starvation and very low growth rate. Water stress might also affect rice roots growth and its capability of nutrient and water absorption. The water stress affected plant phenology because the recovery period after each cycle of stress and watering resulted in delaying or accelerating heading date based the intensity of water stress and rice variety in self. Similar data had been reported by El-Ekhtyar (2004), Zayed et al. (2007), and Majid (2012).

Results of variation analysis show that measured properties ofplant height, tillers number, panicles number, number of filled grains panicle-1, sterility\%, and weight of 1000 grain have a significant difference in irrigation intervals. Prolonging irrigation intervals up to 9 days significantly diminished the yield attributes giving the lowest values of these properties. The continuous flooding (CF) gave the highest values of number of tillers, number of panicles, filled grainspanicle-1 and 1000-grain weight without significant differences with those produced by 6-irrigation interval in the first season regarding the first two traits (Table5\&9). Meanwhile, the CF treatment gave the lowest values of sterility\% in both seasons (Table5\&9). In the second season, both irrigation intervals of CF and 6-day were at the same level of significant regarding sterility \%. Since water stress significantly might be restricted rice growth and other metabolism processes of rice plants as well as increasing catabolism against anabolism that resulted poor yield attributes. Similar results under drill seeded rice had been reported by El-Ekhtyar (2004) and Ali et al.(2012).

Data inserted in Table 13 showed that the irrigation intervals had significant effect of grain and straw yields in both seasons. On the other way, the irrigation intervals didn't show any significant effect of harvest index in the 2012 and 2013 seasons. The CF treatment gave the highest values of grain and straw yields in both seasons. Interestingly, the irrigation treatments of CF and 6-days interval were statically placed at the same group regarding the grain and straw yields in both seasons. Thereby, the irrigation interval of 6 days could be recommended under current water shortage and tolerant varieties such as Giza 179 as well as drill seeded rice. The minimum values of rice grain yield were produced when rice plants were irrigated every 9 days 
in both seasons of study (Table13). Water stress significantly restricted yield components particularly, plant population/unit area, bearing tillers number $\mathrm{m}$ 2 , and panicle characteristics involving, filled grains, weights of panicle and individual grain. Furthermore, the water stress might be affected panicle peduncle elongation, assimilates translocation due to more exertion of ABA which blocks this translocation, affecting current photosynthesis resulted in low grain filling rate. In addition, water stress might affect the root system growth and its ability of nutrient and water uptake resulted in shoot growth inhibition and ultimately declined rice grain yield. Similar results were claimed by El-Ekhtyar(2004),Majid (2012)and Ali et al.( 2012).

Table 2:Effect of irrigation intervals and nitrogen levels on heading date, flag leaf area, leaf area index and chlorophyll content of Giza 179 rice cultivar during 2012 and 2013 seasons.

\begin{tabular}{|c|c|c|c|c|c|c|c|c|}
\hline \multirow[t]{2}{*}{ Treatments } & \multicolumn{2}{|c|}{$\begin{array}{l}\text { Heading } \\
\text { date(days) }\end{array}$} & \multicolumn{2}{|c|}{ Flag leaf area $\left(\mathrm{cm}^{2}\right)$} & \multicolumn{2}{|c|}{$\begin{array}{c}\text { Leaf area } \\
\text { index(LAI) }\end{array}$} & \multicolumn{2}{|c|}{$\begin{array}{c}\text { Leaf chlorophyl } \\
\text { content (SPAD } \\
\text { value }\end{array}$} \\
\hline & 2012 & 2013 & 2012 & 2013 & 2012 & 2013 & 2012 & 2014 \\
\hline $\begin{array}{l}\text { A:Irrigation intervals } \\
\text { Continuous } \\
\text { flooding(CF) } \\
\text { Irrigation every } 6 \text { days } \\
\text { Irrigation every } 9 \text { days }\end{array}$ & $\begin{array}{l}91.9 b \\
94.4 a \\
95.3 a\end{array}$ & $\begin{array}{l}90.6 c \\
92.8 b \\
94.7 a\end{array}$ & $\begin{array}{l}24.02 a \\
22.94 b \\
17.32 c\end{array}$ & $\begin{array}{l}24.28 a \\
23.34 b \\
17.43 c\end{array}$ & $\begin{array}{l}6.19 a \\
6.13 a \\
5.04 b\end{array}$ & $\begin{array}{l}6.36 a \\
6.24 b \\
5.12 b\end{array}$ & $\begin{array}{l}33.24 a \\
32.07 b \\
27.96 c\end{array}$ & $\begin{array}{l}32.56 a \\
31.04 b \\
27.23 c\end{array}$ \\
\hline F. Test & * & ** & ** & $\star \star$ & ** & $\star \star$ & ** & ** \\
\hline $\begin{array}{l}\text { B: Nitrogen levels }\left(\mathrm{kg} \mathrm{Nha}^{-1}\right) \\
0 \\
110 \\
165 \\
220\end{array}$ & $\begin{array}{l}90.8 d \\
92.9 c \\
95.2 b \\
96.5 a\end{array}$ & $\begin{array}{l}88.7 c \\
92.1 \mathrm{~b} \\
94.6 \mathrm{a} \\
95.4 \mathrm{a}\end{array}$ & $\begin{array}{l}17.52 c \\
20.81 b \\
23.23 a \\
24.17 a\end{array}$ & $\begin{array}{l}16.99 c \\
21.27 b \\
23.84 a \\
24.63 a\end{array}$ & $\begin{array}{l}4.83 \mathrm{c} \\
5.58 \mathrm{~b} \\
6.21 \mathrm{a} \\
6.64 \mathrm{a}\end{array}$ & $\begin{array}{l}4.85 d \\
5.76 c \\
6.27 b \\
6.73 a\end{array}$ & $\begin{array}{l}28.21 \mathrm{c} \\
31.03 \mathrm{~b} \\
32.19 \mathrm{a} \\
32.88 \mathrm{a}\end{array}$ & $\begin{array}{l}27.82 c \\
29.98 b \\
31.27 a \\
32.05 a\end{array}$ \\
\hline F. Test & * & * & $\star \star$ & ** & $\star *$ & $\star *$ & $\star \star$ & $\star \star$ \\
\hline $\mathrm{A} \times \mathrm{B}$ Interaction: & N.S & N.S & ** & ** & ** & ** & NS & NS \\
\hline
\end{tabular}

Means: followed by the same litter (s) are not significantly different, according to DMRT.*, ${ }^{* \star}$ and N.S.: Significant at 0.05 and 0.01 levels and not significant, respectively.

Table 3: Effect of the interaction between irrigation intervals and nitrogen levels on flag leaf area $\left(\mathrm{cm}^{2}\right)$ of Giza 179 rice cultivar during 2012 and 2013 seasons.

\begin{tabular}{|c|c|c|c|c|c|c|c|}
\hline \multirow{3}{*}{$\begin{array}{l}\text { Nitrogen } \\
\left(\mathrm{kg} \mathrm{Nha}^{-1}\right)\end{array}$} & \multirow{3}{*}{ levels } & \multicolumn{6}{|c|}{ Irrigation intervals } \\
\hline & & \multicolumn{3}{|c|}{2012} & \multicolumn{3}{|c|}{2013} \\
\hline & & $\begin{array}{c}\text { Continuous } \\
\text { flooding }\end{array}$ & $\begin{array}{c}\text { Irrigation } \\
\text { every } 6 \\
\text { days }\end{array}$ & $\begin{array}{c}\text { Irrigation } \\
\text { every } 9 \\
\text { days }\end{array}$ & $\begin{array}{c}\text { Continuous } \\
\text { flooding }\end{array}$ & $\begin{array}{c}\text { Irrigation } \\
\text { every } 6 \\
\text { days }\end{array}$ & $\begin{array}{c}\text { Irrigation } \\
\text { every } 9 \\
\text { days }\end{array}$ \\
\hline 0 & & 19.12ef & $19.80 \mathrm{e}$ & $13.63 \mathrm{~g}$ & 18.49gh & $19.53 \mathrm{fg}$ & $12.94 \mathrm{i}$ \\
\hline 110 & & $22.95 \mathrm{~cd}$ & $22.19 d$ & $17.28 f$ & 23.67de & $22.79 \mathrm{e}$ & $17.36 \mathrm{~h}$ \\
\hline 165 & & $26.68 a$ & $24.05 b c$ & 18.96 ef & $27.15 a b$ & $24.89 \mathrm{~cd}$ & $19.48 f g$ \\
\hline 220 & & $27.35 a$ & 25.73ab & $19.42 \mathrm{e}$ & $27.81 \mathrm{a}$ & $26.16 \mathrm{bc}$ & $19.32 f$ \\
\hline
\end{tabular}

Means: followed by the same litter (s) are not significantly different, according to DMRT. 
Table 4:Effect of the interaction between irrigation intervals and nitrogen levels on leaf area index(LAl) of Giza 179 rice cultivar during 2012 and 2013 seasons

\begin{tabular}{|c|c|c|c|c|c|c|c|}
\hline \multirow[b]{3}{*}{$\begin{array}{l}\text { Nitrogen } \\
\left(\mathbf{k g ~ N h a}^{-1}\right)\end{array}$} & \multirow{3}{*}{ levels } & \multicolumn{6}{|c|}{ Irrigation intervals } \\
\hline & & \multicolumn{3}{|c|}{2012} & \multicolumn{3}{|c|}{2013} \\
\hline & & $\begin{array}{c}\text { Continuous } \\
\text { flooding }\end{array}$ & $\begin{array}{c}\text { Irrigation } \\
\text { every } 6 \\
\text { days }\end{array}$ & $\begin{array}{c}\text { Irrigation } \\
\text { every } 9 \\
\text { days }\end{array}$ & $\begin{array}{c}\text { Continuous } \\
\text { flooding }\end{array}$ & $\begin{array}{c}\text { Irrigation } \\
\text { every } 6 \\
\text { days }\end{array}$ & $\begin{array}{c}\text { Irrigation } \\
\text { every } 9 \\
\text { days }\end{array}$ \\
\hline 0 & & 5.23 & $5.10 \mathrm{~g}$ & $4.16 \mathrm{i}$ & $5.26 \mathrm{e}$ & 5.02ef & $4.27 \mathrm{~g}$ \\
\hline 110 & & $6.09 \mathrm{~cd}$ & $5.97 \mathrm{~d}$ & $4.69 \mathrm{~h}$ & $6.37 b c$ & $6.18 c$ & $4.73 f$ \\
\hline 165 & & $6.46 a b$ & $6.42 b c$ & $5.57 \mathrm{ef}$ & $6.59 b$ & $6.55 b c$ & $5.68 d$ \\
\hline 220 & & $7.17 \mathrm{a}$ & $7.03 a$ & 5.74de & $7.21 \mathrm{a}$ & $7.19 a$ & $5.79 d$ \\
\hline
\end{tabular}

Means: followed by the same litter (s) are not significantly different, according to DMRT.

\section{Effect of nitrogen levels:}

Nitrogen treatments significantly influenced the growth; heading date, flag leaf area, leaf area index (LAl) and chlorophyll content of rice in the two study seasons (Table 2). The measured growth parameters significantly responded to nitrogen up to $220 \mathrm{~kg}$ and there were progressive improvements on growth of rice. Both nitrogen levels of 165 and 220 were put at one group of significant. The lowest values growth properties were recorded with zero nitrogen application, while the highest values were with higher nitrogen level of $220 \mathrm{~kg} \mathrm{Nha}^{-1}$. This could be owing to low available $\mathrm{N}$ status of the soil and ion imbalance under drill seeded rice because high plant density. It was observed that increasing nitrogen level up to $220 \mathrm{~kg} \mathrm{ha}^{-1}$ significantly retarded heading.As seen in Table 2, none of nitrogen application shortened the period from sowing to heading giving early heading date, under current drill seeded rice. Zayed et al.(2005) claimed that both low nitrogen availability accelerates the heading and shortened the vegetative period resulted in less dry mater production at pre-heading that might be produced low grain yield .Similar results were indicated by El-Habet, Howida et al.(2013).

Plant height and number of tiller $\mathrm{m}^{-2}$ were significantly increased as nitrogen levels increased up to $220 \mathrm{~kg} \mathrm{~N}^{-1}$ (Table 5). The higher nitrogen level of $220 \mathrm{~kg} \mathrm{~N}^{-1}$ hecorded the highest values of plant height and tillers number $\mathrm{m}^{-2}$, while the lowest values of them were produced by non-nitrogen fertilizer. Nitrogen fertilizer treatments had significant and positive impact on yield attributes in both seasons (Tables5\&9). Increasing nitrogen level up to $220 \mathrm{~kg} \mathrm{Nha}^{-1}$ significantly increased panicle numbers $\mathrm{m}^{-2}$ and filled grains panicle ${ }^{-1}$, but the increment in 1000- grain weight was up to $165 \mathrm{~kg} \mathrm{ha}^{-1}$. However, increasing nitrogen rates up to $220 \mathrm{~kg} \mathrm{ha}^{-1}$ reduced 1000 -grain weight without significant mean with that of $165 \mathrm{kgNha}^{-1}$. The rate of $220 \mathrm{~kg}$ $\mathrm{ha}^{-1}$ failed to lower the number of unfilled grains \% comparing only with its proceeding rate of $165 \mathrm{~kg} \mathrm{Nha}^{-1}$. The latter nitrogen level of $165 \mathrm{kgNha}^{-1}$ gave the lowest values of sterility\% in both seasons (Table 9).

The zero nitrogen application exerted the highest values of sterility\%. In the two season of study, the nitrogen of 220 and $165 \mathrm{~kg} \mathrm{Nha}^{-1}$ levels were at apar regarding panicles number and filled grains /panicle. At the same time, the treatment of zero nitrogen application recoded the lowest values of 
yield attributes. The improvement of the yield attributes as a result of increasing nitrogen levels might due to increase translocation of photosynthesis from source to sink during grain filling as well as improving rice growth traits and grain filling. That might be due to stimulate the vigorous growth superficial roots increased the synthesis of cytokinins ( mainly Zeatian ) in roots, and delayed the appearance of the absesic acid (ABA) peak in both leaves and filling grains. High ratio of Zeatian /ABA enhanced the synthesis of RNA, which resulted in protein synthesis for carbon assimilation and transportation (Yang and Sun., 1992). Zayed et al.(2007) and ElHabat,Howidaet al.(2013) reached similar results.

The nitrogen levels significantly improved and affected rice grain and straw yields as well as harvest index in the first and second seasons, respectively (Table13). The grain and straw yields gradually increased as nitrogen levels were increases up to $220 \mathrm{kgNha}^{-1}$. For rice grain yield, the nitrogen level of $220 \mathrm{kgNha}^{-1}$ gave the highest values of grain yield without significant differences with those released by nitrogen level of $165 \mathrm{kgNha}^{-1}$ in both seasons of study(Table13). The maximum values of straw yield were exerted by higher nitrogen level in the two seasons of study. Harvest index recorded its highest value with nitrogen level of $165 \mathrm{kgNha}^{-1}$ without any significant differences with those produced by nitrogen level of $110 \mathrm{~kg} \mathrm{Nha}^{-1}$ in the first and second season(Table13). It seems that the higher nitrogen level of $220 \mathrm{~kg} \mathrm{Nha}^{-1}$ was being ineffective in improving harvest index since it failed to produce more grain against straw. Moreover, increasing nitrogen beyond $165 \mathrm{kgNha}^{-1}$ significantly reduced the harvest index in the two seasons of study (Table 13). The lowest values of yields and harvest index were recorded when rice plants didn't receive any applied nitrogen. A significant higher grain yield at the highest level of nitrogen was obtained ,might be owing to better $\mathrm{N}$ uptake leading to greater dry matter production and its translocation to the sink. Increased panicle numbers hill ${ }^{-1}$, filled grains panicle ${ }^{-1}$ and grain weight were mainly responsible for the increased yield at this level of nitrogen. Majid (2012) and El-Habet,Howida et al.(2013) came to similar results.

Table 5: Effect of irrigation intervals and nitrogen levels on plant height, number of tillersm ${ }^{-2}$ and number of panicles $\mathrm{m}^{2}{ }^{2}$ of Giza 179 rice cultivar during 2013 and 2013 seasons.

\begin{tabular}{|c|c|c|c|c|c|c|}
\hline \multirow{2}{*}{ Treatments } & \multicolumn{2}{|c|}{ Plant height(cm) } & \multicolumn{2}{|c|}{ Number of tillersm- ${ }^{2}$} & \multicolumn{2}{|c|}{ Number of panicles $\mathrm{m}^{2}{ }^{2}$} \\
\hline & 2012 & 2013 & 2012 & 2013 & 2012 & 2013 \\
\hline A:Irrigation intervals & & & & & & \\
\hline Continuous flooding(CF) & $92.8 \mathrm{a}$ & $91.7 \mathrm{a}$ & $493 a$ & $482 a$ & $490 a$ & $487 a$ \\
\hline Irrigation every 6 days & $91.2 b$ & $90.5 b$ & $478 \mathrm{~b}$ & $469 \mathrm{~b}$ & $476 a$ & $466 b$ \\
\hline Irrigation every 9 days & $88.7 \mathrm{c}$ & $87.8 \mathrm{c}$ & $427 c$ & $418 \mathrm{c}$ & $425 b$ & $416 \mathrm{c}$ \\
\hline F. Test & ** & ** & ** & ** & ** & ** \\
\hline B:Nitrogen levels $\left(\mathrm{kg} \mathrm{Nha}^{-1}\right)$ : & & & & & & \\
\hline & $85.7 d$ & $84.9 \mathrm{c}$ & $392 d$ & $379 c$ & $391 d$ & $375 c$ \\
\hline 110 & $90.3 \mathrm{c}$ & $88.7 \mathrm{~b}$ & $465 c$ & $457 \mathrm{~b}$ & $462 c$ & $454 b$ \\
\hline 165 & $92.5 b$ & $92.6 a$ & $496 b$ & $491 \mathrm{a}$ & $493 b$ & $488 a$ \\
\hline 220 & $94.9 a$ & $93.8 \mathrm{a}$ & $512 a$ & $498 a$ & $509 a$ & $497 a$ \\
\hline F. Test & ** & ** & ** & ** & ** & ** \\
\hline Ax B Interaction: & ** & ** & * & * & * & * \\
\hline
\end{tabular}

DMRT. ${ }^{*},{ }^{* *}$ and N.S.: Significant at 0.05 and 0.01 levels and not significant, respectively. 
Table 6:Effect of the interaction between irrigation intervals and nitrogen levels on plant height $(\mathrm{cm})$ of Giza 179 rice cultivar during 2012 and 2013 seasons

\begin{tabular}{|l|c|c|c|c|c|c|}
\hline \multirow{2}{*}{$\begin{array}{l}\text { Nitrogen } \\
\text { (kg Nha }^{-1} \text { ) }\end{array}$} & \multicolumn{6}{|c|}{ Irrigation intervals } \\
\cline { 2 - 7 } & levels & \multicolumn{3}{|c|}{$\mathbf{2 0 1 3}$} \\
\cline { 2 - 7 } & $\begin{array}{c}\text { Continuous } \\
\text { flooding }\end{array}$ & $\begin{array}{c}\text { Irrigation } \\
\text { every 6 } \\
\text { days }\end{array}$ & $\begin{array}{c}\text { Irrigation } \\
\text { every 9 } \\
\text { days }\end{array}$ & $\begin{array}{c}\text { Continuous } \\
\text { flooding }\end{array}$ & $\begin{array}{c}\text { Irrigation } \\
\text { every 6 } \\
\text { days }\end{array}$ & $\begin{array}{c}\text { Irrigation } \\
\text { every 9 } \\
\text { days }\end{array}$ \\
\hline 0 & $88.4 \mathrm{~g}$ & $85.4 \mathrm{i}$ & $83.3 \mathrm{j}$ & $87.9 \mathrm{e}$ & $84.7 \mathrm{~g}$ & $82.1 \mathrm{~h}$ \\
110 & $92.5 \mathrm{de}$ & $91.3 \mathrm{ef}$ & $87.1 \mathrm{~h}$ & $90.2 \mathrm{~d}$ & $89.6 \mathrm{~d}$ & $86.3 \mathrm{f}$ \\
165 & $94.3 \mathrm{bc}$ & $92.8 \mathrm{~d}$ & $90.5 \mathrm{f}$ & $93.4 \mathrm{~b}$ & $83.8 \mathrm{~b}$ & $90.7 \mathrm{~d}$ \\
220 & $95.8 \mathrm{a}$ & $95.2 \mathrm{ab}$ & $93.7 \mathrm{~cd}$ & $95.3 \mathrm{a}$ & $93.9 \mathrm{~b}$ & $92.2 \mathrm{c}$ \\
\hline
\end{tabular}

Means: followed by the same litter (s) are not significantly different, according to DMRT.

Table 7:Effect of the interaction between irrigation intervals and nitrogen levels on number of tillers $/ \mathrm{m}^{-2}$ of Giza 179 rice cultivar during 2012 and 2013 seasons

\begin{tabular}{|l|c|c|c|c|c|c|}
\hline \multirow{2}{*}{$\begin{array}{l}\text { Nitrogen } \\
\left(\mathbf{k g ~ N h a}^{-1}\right)\end{array}$} & \multicolumn{5}{|c|}{ Irrigation intervals } \\
\cline { 2 - 7 } & \multicolumn{3}{|c|}{$\mathbf{2 0 1 2}$} & \multicolumn{4}{c|}{$\mathbf{2 0 1 3}$} \\
\cline { 2 - 7 } & $\begin{array}{c}\text { Continuous } \\
\text { flooding }\end{array}$ & $\begin{array}{c}\text { Irrigation } \\
\text { every 6 } \\
\text { days }\end{array}$ & $\begin{array}{c}\text { Irrigation } \\
\text { every 9 } \\
\text { days }\end{array}$ & $\begin{array}{c}\text { Continuous } \\
\text { flooding }\end{array}$ & $\begin{array}{c}\text { Irrigation } \\
\text { every 6 } \\
\text { days }\end{array}$ & $\begin{array}{c}\text { Irrigation } \\
\text { every 9 } \\
\text { days }\end{array}$ \\
\hline 0 & $416 \mathrm{f}$ & $397 \mathrm{~g}$ & $363 \mathrm{~h}$ & $405 \mathrm{e}$ & $398 \mathrm{e}$ & $334 \mathrm{f}$ \\
110 & $492 \mathrm{c}$ & $482 \mathrm{~cd}$ & $421 \mathrm{f}$ & $486 \mathrm{~b}$ & $456 \mathrm{c}$ & $429 \mathrm{~d}$ \\
165 & $523 \mathrm{~b}$ & $515 \mathrm{~b}$ & $448 \mathrm{e}$ & $512 \mathrm{a}$ & $509 \mathrm{a}$ & $452 \mathrm{c}$ \\
220 & $541 \mathrm{a}$ & $519 \mathrm{~b}$ & $476 \mathrm{~d}$ & $523 \mathrm{a}$ & $514 \mathrm{a}$ & $458 \mathrm{c}$ \\
\hline
\end{tabular}

Means: followed by the same litter (s) are not significantly different, according to DMRT.

Table8:Effect of the interaction between irrigation intervals and nitrogen levels on number of panicles $\mathrm{m}^{-2}$ of Giza 179 rice cultivar during 2012 and 2013 seasons.

\begin{tabular}{|c|c|c|c|c|c|c|}
\hline \multirow{3}{*}{$\begin{array}{l}\text { Nitrogen } \\
\text { levels } \\
\mathrm{Nha}^{-1} \text { ) }\end{array}$} & \multicolumn{6}{|c|}{ Irrigation intervals } \\
\hline & \multicolumn{3}{|c|}{2012} & \multicolumn{3}{|c|}{2013} \\
\hline & $\begin{array}{c}\text { Continuous } \\
\text { flooding }\end{array}$ & $\begin{array}{c}\text { Irrigation } \\
\text { every } 6 \\
\text { days }\end{array}$ & $\begin{array}{c}\text { Irrigation } \\
\text { every } 9 \\
\text { days }\end{array}$ & $\begin{array}{c}\text { Continuous } \\
\text { flooding }\end{array}$ & $\begin{array}{c}\text { Irrigation } \\
\text { every } 6 \\
\text { days }\end{array}$ & $\begin{array}{c}\text { Irrigation } \\
\text { every } 9 \\
\text { days }\end{array}$ \\
\hline $\begin{array}{l}0 \\
110\end{array}$ & $\begin{array}{c}412 \mathrm{f} \\
491 \mathrm{~cd}\end{array}$ & $\begin{array}{l}394 f \\
479 d\end{array}$ & $\begin{array}{l}367 g \\
417 f\end{array}$ & $\begin{array}{l}402 e \\
481 b\end{array}$ & $\begin{array}{l}393 e \\
454 c\end{array}$ & $\begin{array}{l}329 f \\
428 d\end{array}$ \\
\hline 165 & $520 a b$ & $513 \mathrm{bc}$ & $446 e$ & $501 a$ & $507 a$ & $449 c$ \\
\hline 220 & $539 a$ & $517 a b$ & $471 d$ & $564 a$ & $511 \mathrm{a}$ & $456 c$ \\
\hline
\end{tabular}

Means: followed by the same litter (s) are not significantly different, according to DMRT.

Table 9: Some yield components of Giza 179 rice cultivar as influenced by irrigation intervals and nitrogen levels during 2012 and 2013 seasons

\begin{tabular}{|c|c|c|c|c|c|c|}
\hline \multirow[t]{2}{*}{ Treatments } & \multicolumn{2}{|c|}{$\begin{array}{l}\text { Number of filled } \\
\text { grains/panicle }\end{array}$} & \multicolumn{2}{|c|}{$\begin{array}{c}\text { Sterility } \\
\text { percentage }\end{array}$} & \multicolumn{2}{|c|}{$\begin{array}{c}\text { 1000-grain weight } \\
\text { (g) }\end{array}$} \\
\hline & 2012 & 2013 & 2012 & 2013 & 2012 & 2013 \\
\hline A. Irrigation intervals & & & & & & \\
\hline Continuous flooding(CF) & $111.6 a$ & $108.8 \mathrm{a}$ & $5.01 b$ & $4.79 b$ & $27.13 a$ & $27.29 a$ \\
\hline Irrigation every 6 days & $110.0 \mathrm{a}$ & $104.4 \mathrm{~b}$ & $4.83 c$ & $4.84 b$ & $26.49 b$ & $26.57 \mathrm{~b}$ \\
\hline Irrigation every 9 days & $90.4 \mathrm{~b}$ & $86.8 \mathrm{c}$ & $6.49 a$ & $6.41 \mathrm{a}$ & $24.64 \mathrm{c}$ & $24.84 \mathrm{c}$ \\
\hline F. Test & $\star *$ & ** & ** & * & ** & ** \\
\hline B.Nitrogen levels $\left(\mathrm{kg} \mathrm{Nha}^{-1}\right)$ & & & & & & \\
\hline 0 & $84.5 d$ & $79.2 d$ & $6.02 a$ & $5.87 a$ & $25.39 c$ & $25.65 c$ \\
\hline 110 & $97.6 \mathrm{c}$ & $93.5 \mathrm{c}$ & $5.54 \mathrm{~b}$ & $5.47 \mathrm{~b}$ & $25.85 b$ & $26.02 \mathrm{~b}$ \\
\hline 165 & $113.9 b$ & $108.8 \mathrm{~b}$ & $4.99 d$ & $4.96 \mathrm{c}$ & $26.57 \mathrm{a}$ & $26.68 \mathrm{a}$ \\
\hline 220 & $120.0 \mathrm{a}$ & $118.3 a$ & $5.22 \mathrm{c}$ & $5.08 \mathrm{c}$ & $26.53 a$ & $26.59 a$ \\
\hline F. Test & ** & $\star *$ & $\star *$ & $\star *$ & $\star *$ & ** \\
\hline$A \times B$ Interaction: & ** & ** & ** & ** & ** & ** \\
\hline
\end{tabular}

Means: followed by the same litter (s) are not significantly different, according to DMRT. *,* and N.S.: Significant at 0.05 and 0.01 levels and not significant, respectively. 
Table 10:Effect of the interaction between irrigation intervals and nitrogen levels on number of filled grains/panicle of Giza 179 rice cultivar during 2012 and 2013 seasons.

\begin{tabular}{|l|c|c|c|c|c|c|}
\hline \multirow{2}{*}{$\begin{array}{l}\text { Nitrogen levels } \\
\left.\text { (kg Nha }^{-1}\right)\end{array}$} & \multicolumn{5}{|c|}{$\mathbf{2 0 1 2}$} & \multicolumn{3}{|c|}{$\mathbf{2 0 1 3}$} \\
\cline { 2 - 7 } & $\begin{array}{c}\text { Continuous } \\
\text { flooding }\end{array}$ & $\begin{array}{c}\text { Irrigation } \\
\text { every 6 6 } \\
\text { days }\end{array}$ & $\begin{array}{c}\text { Irrigation } \\
\text { every 9 } \\
\text { days }\end{array}$ & $\begin{array}{c}\text { Continuous } \\
\text { flooding }\end{array}$ & $\begin{array}{c}\text { Irrigation } \\
\text { every 6 } \\
\text { days }\end{array}$ & $\begin{array}{c}\text { Irrigation } \\
\text { every 9 } \\
\text { days }\end{array}$ \\
\hline 0 & $91.3 \mathrm{~g}$ & $88.2 \mathrm{~h}$ & $74.1 \mathrm{j}$ & $92.4 \mathrm{~g}$ & $79.9 \mathrm{i}$ & $65.4 \mathrm{j}$ \\
110 & $103.7 \mathrm{e}$ & $105.5 \mathrm{~d}$ & $83.5 \mathrm{i}$ & $105.4 \mathrm{~d}$ & $92.6 \mathrm{~g}$ & $82.5 \mathrm{~h}$ \\
165 & $122.4 \mathrm{c}$ & $121.0 \mathrm{c}$ & $98.2 \mathrm{f}$ & $111.6 \mathrm{c}$ & $118.1 \mathrm{~b}$ & $96.7 \mathrm{f}$ \\
220 & $128.9 \mathrm{a}$ & $125.4 \mathrm{~b}$ & $105.6 \mathrm{~d}$ & $125.6 \mathrm{a}$ & $126.8 \mathrm{a}$ & $102.4 \mathrm{e}$ \\
\hline
\end{tabular}

Means: followed by the same litter (s) are not significantly different, according to DMRT.

Table 11: Effect of the interaction between irrigation intervals and nitrogen levels on sterility percentage of Giza 179 rice cultivar during 2012and 2013 seasons.

\begin{tabular}{|l|c|c|c|c|c|c|}
\hline \multirow{2}{*}{$\begin{array}{l}\text { Nitrogen levels } \\
\text { (kg Nha }^{-1} \text { ) }\end{array}$} & \multicolumn{5}{|c|}{ Irrigation intervals } \\
\cline { 2 - 7 } & $\begin{array}{c}\text { Continuous } \\
\text { flooding }\end{array}$ & $\begin{array}{c}\text { Irrigation } \\
\text { every 6 } \\
\text { days }\end{array}$ & $\begin{array}{c}\text { Irrigation } \\
\text { every 9 } \\
\text { days }\end{array}$ & $\begin{array}{c}\text { Continuous } \\
\text { flooding }\end{array}$ & $\begin{array}{c}\text { Irrigation } \\
\text { every 6 } \\
\text { days }\end{array}$ & $\begin{array}{c}\text { Irrigation } \\
\text { every 9 } \\
\text { days }\end{array}$ \\
\hline 0 & $5.37 \mathrm{e}$ & $5.68 \mathrm{~d}$ & $7.01 \mathrm{a}$ & $5.26 \mathrm{~cd}$ & $5.52 \mathrm{c}$ & $6.84 \mathrm{a}$ \\
110 & $5.10 \mathrm{ef}$ & $5.25 \mathrm{e}$ & $6.26 \mathrm{bc}$ & $4.99 \mathrm{~d}$ & $5.20 \mathrm{~d}$ & $6.22 \mathrm{~b}$ \\
165 & $4.72 \mathrm{~g}$ & $4.11 \mathrm{~h}$ & $6.14 \mathrm{c}$ & $4.53 \mathrm{e}$ & $4.33 \mathrm{e}$ & $6.02 \mathrm{~b}$ \\
220 & $4.85 \mathrm{fg}$ & $4.29 \mathrm{~h}$ & $6.53 \mathrm{~b}$ & $4.36 \mathrm{e}$ & $4.31 \mathrm{e}$ & $6.57 \mathrm{a}$ \\
\hline
\end{tabular}

Means: followed by the same litter (s) are not significantly different, according to DMRT.

Table 12: Effect of the interaction between irrigation intervals and nitrogen levels on 1000-grain weight $(\mathrm{g})$ of Giza 179 rice cultivar during 2012 and 2013 seasons

\begin{tabular}{|c|c|c|c|c|c|c|c|}
\hline \multirow[b]{3}{*}{$\begin{array}{l}\text { Nitrogen } \\
\left(\text { kg Nha }^{-1}\right)\end{array}$} & \multirow{3}{*}{ levels } & \multicolumn{6}{|c|}{ Irrigation intervals } \\
\hline & & \multicolumn{3}{|c|}{2012} & \multicolumn{3}{|c|}{2013} \\
\hline & & $\begin{array}{c}\text { Continuous } \\
\text { flooding }\end{array}$ & $\begin{array}{c}\text { Irrigation } \\
\text { every } 6 \\
\text { days }\end{array}$ & $\begin{array}{c}\text { Irrigation } \\
\text { every } 9 \\
\text { days }\end{array}$ & $\begin{array}{c}\text { Continuous } \\
\text { flooding }\end{array}$ & $\begin{array}{c}\text { Irrigation } \\
\text { every } 6 \\
\text { days }\end{array}$ & $\begin{array}{c}\text { Irrigation } \\
\text { every } 9 \\
\text { days }\end{array}$ \\
\hline 0 & & 26.16de & $25.54 \mathrm{ef}$ & $24.47 \mathrm{~g}$ & $26.29 \mathrm{~cd}$ & $25.74 \mathrm{de}$ & 24.92ef \\
\hline 110 & & $26.89 \mathrm{bcd}$ & $26.38 \mathrm{~cd}$ & $24.29 \mathrm{~g}$ & $27.11 b c$ & $26.49 \mathrm{~cd}$ & $24.46 f$ \\
\hline 165 & & $28.02 a$ & $26.92 b c$ & $24.76 \mathrm{~g}$ & $28.23 a$ & $27.01 \mathrm{bc}$ & $24.80 f$ \\
\hline 220 & & $27.43 a b$ & $27.13 b c$ & $25.04 \mathrm{fg}$ & $27.54 a b$ & $27.05 b c$ & 25.18 ef \\
\hline
\end{tabular}

Means: followed by the same litter (s) are not significantly different, according to DMRT.

The interaction effect:

Variation analysis of data indicated that the interaction between irrigation intervals and nitrogen levels had significant effect on flag leaf area and leaf area index in both seasons. The combinations of CF with $\mathrm{N}$ level of $220 \mathrm{~kg} \mathrm{Nha}^{-1}$ gave the highest values of both mentioned traits. Contrary, the lowest values of them were with the combination of zero nitrogen application and irrigation intervals of 9 days in both seasons (Tables 3 and 4). The three combinations of CF with165 kg Nha ${ }^{-1}$, CF with220 kgNha ${ }^{-1}$ and 6 days with 
$220 \mathrm{~kg}$ were at the same level of significant in the first season, while, in the second season, the couple combinations of CF with220 kg Nha-1 and 6 days with $220 \mathrm{~kg}$ showed similar pattern in both traits (Table3). Moreover, under long irrigation interval of 9 days the higher nitrogen level of $220 \mathrm{~kg} \mathrm{Nha}^{-1}$ was being effective in relieving the effect of water stress on plant growth.Furthermore, nitrogen application at the higher rate could ameliorate the undesirable effect of water stress of prolonged irrigation interval of 9 days by developing extensive root growth, large leaf area, more dry matter production and considerable net photosynthesis. The well root growth induced by higher nitrogen level under prolonged irrigation interval of 9 days enable stressed rice plants to take an adequate water and nutrient keeping health growth. At the same time supplying plant by an adequate nitrogen could delay early aging in the terms of senescence happened by water stress ensuring optimum growth and yield even with water stress.

Data listed in Tables 6\&7 indicated that the interaction between irrigation intervals and nitrogen levels had significant effect on plant height and tillers number in both seasons. The combination of nitrogen level of 220 $\mathrm{kg} \mathrm{Nha}^{-1}$ and continuous flooding produced the highest values of plant height and tillers numberhill ${ }^{-1}$ in both seasons without any significant differences with those produced by the same nitrogen level with irrigation interval of 6 day in in 2012 and 2013, respectively. The lowest means of plant height and tillers number were recorded when rice plant irrigated every 9 days under zero nitrogen level in both seasons of study. That means increasing nitrogen could alleviate the stress effect of water on growth (Majid, 2012)

The interaction between irrigation intervals and nitrogen level had significant effect on number of paniclem ${ }^{-2}$, number of filled grains panicle ${ }^{-1}$, sterility\%, and 1000 -grain weight in both seasons of study. The combination of $\mathrm{CF}$ and nitrogen level of $220 \mathrm{~kg} \mathrm{Nha}^{-1}$ produced the highest value of panicles number without significant differences with those produced by the same nitrogen level under 6-day interval (Tables8). The worst combination was zero nitrogen level with 9-days interval. As for, filled grains panicle ${ }^{-1}$, the lowest values of filled grainspanicle ${ }^{-1}$ were obtained by the combination of zero nitrogen level and 9-days interval in both seasons (Table10). The combination of higher nitrogen level of $220 \mathrm{~kg} \mathrm{Nha}^{-1}$ with CF and 6-days interval gave the highest values of filled grainspanicle ${ }^{-1}$ in the first and second seasons, respectively. The lowest mean of sterility\% was recorded with the combination of higher nitrogen level of $220 \mathrm{kgNha}^{-1}$ with $\mathrm{CF}$, while the maximum values of sterility\% was recorded when rice plants didn't receive any nitrogen under the irrigation interval of 9 days(Table11). Regarding 1000grain weight, the highest means of 1000-grain weight was recorded when rice plants were fertilized by the nitrogen level of $165 \mathrm{~kg} \mathrm{Nha}^{-1}$ under continuous flooding in both seasons (Table12). The last combination statically came at the same group with the combination of $220 \mathrm{~kg} \mathrm{Nha}^{-1}$ under continuous flooding. The lowest means of 1000-grain weight were produced by the combination of zero nitrogen level and interval of 9 days in both seasons of study (Table12). Majid (2012) reported similar findings. 
The interaction between irrigation intervals and nitrogen level had significant effect on grain and straw yields in 2012 and 2013 seasons, respectively (Table14). The combination of CF irrigation treatment and nitrogen level of $165 \mathrm{~kg} \mathrm{Nha}^{-1}$ gave the highest values of grain yield in both seasons (Tables 14), while, the combination of $220 \mathrm{~kg} \mathrm{Nha}^{-1}$ and 6 days interval gave the highest value of straw yield in the two seasons of study (Table15). Data analysis variation indicated that the combinations of CF with 165 and $220 \mathrm{kgNha}^{-1}$, and 6-days interval with the same two levels were placed at the same category of significant. The rice straw yield recorded its highest value at the combination of $220 \mathrm{kgNha}^{-1}$ and 6-days interval in both seasons (Table14\&15). Grain and straw yields recorded their lowest means at the combination of zero nitrogen application and 9-days interval in the two seasons of study. From current deliberations, the increasing nitrogen level up to $220 \mathrm{~kg}$ could combat the harmful of water stress induced by prolonged irrigation interval of 9 days. Similar data had been claimed by Majid (2012).

Table 13: Effect of irrigation intervals and nitrogen levels on grain yield, straw yield and harvest index of Giza 179 during 2012 and 2013 seasons.

\begin{tabular}{|c|c|c|c|c|c|c|}
\hline \multirow[t]{2}{*}{ Treatments } & \multicolumn{2}{|c|}{ Grain yield $\left(\right.$ tha $\left.^{-1}\right)$} & \multicolumn{2}{|c|}{ Straw yield $\left(\right.$ tha $\left.^{-1}\right)$} & \multicolumn{2}{|c|}{$\begin{array}{l}\text { Harvest index } \\
(\mathrm{HI})\end{array}$} \\
\hline & 2012 & 2013 & 2012 & 2013 & 2012 & 2013 \\
\hline $\begin{array}{l}\text { A. Irrigation intervals } \\
\text { Continuous flooding } \\
\text { Irrigation every } 6 \text { days } \\
\text { Irrigation every } 9 \text { days }\end{array}$ & $\begin{array}{l}8.79 a \\
8.56 a \\
6.29 b\end{array}$ & $\begin{array}{l}8.86 a \\
8.67 a \\
6.35 b\end{array}$ & $\begin{array}{c}11.99 a \\
12.08 \mathrm{a} \\
9.27 \mathrm{~b}\end{array}$ & $\begin{array}{c}12.13 a \\
12.27 a \\
9.48 b\end{array}$ & $\begin{array}{l}42.26 \\
41.19 \\
40.13\end{array}$ & $\begin{array}{l}42.12 \\
41.22 \\
39.83\end{array}$ \\
\hline F. Test & ${ }^{\star *}$ & ${ }^{* *}$ & ** & ** & NS & NS \\
\hline \begin{tabular}{|l} 
B.Nitrogen levels $\left(\mathrm{kg} \mathrm{Nha}^{-1}.\right)$ : \\
Control \\
110 \\
165 \\
220 \\
\end{tabular} & $\begin{array}{l}5.18 \mathrm{c} \\
7.95 \mathrm{~b} \\
9.02 \mathrm{a} \\
9.36 \mathrm{a}\end{array}$ & $\begin{array}{l}5.23 c \\
8.01 b \\
9.14 a \\
9.45 a \\
\end{array}$ & $\begin{array}{l}7.72 \mathrm{~d} \\
11.06 \mathrm{c} \\
12.27 \mathrm{~b} \\
13.38 \mathrm{a} \\
\end{array}$ & $\begin{array}{c}7.83 d \\
11.29 \mathrm{c} \\
12.41 \mathrm{~b} \\
13.64 \mathrm{a} \\
\end{array}$ & $\begin{array}{l}39.92 c \\
41.71 a \\
42.19 a \\
40.97 b\end{array}$ & $\begin{array}{l}40.01 c \\
41.39 a \\
41.96 a \\
40.86 b\end{array}$ \\
\hline F. Test & ** & ** & ** & ** & ** & ** \\
\hline Ax B Interaction: & ** & ** & * & * & NS & NS \\
\hline
\end{tabular}

Means: followed by the same litter (s) are not significantly different, according to DMRT. ${ }^{\star * *}$ and N.S.: Significant at 0.05 and 0.01 levels and not significant, respectively.

Table 14:Effect of the interaction between irrigation intervals and nitrogen levels on grain yield $\left(\right.$ tha $\left.^{-1}\right)$ of Giza 179 rice cultivar during 2012 and 2013 seasons.

\begin{tabular}{|l|c|c|c|c|c|c|}
\hline \multirow{2}{*}{$\begin{array}{l}\text { Nitrogen } \\
\text { (kg Nha }^{-1} \text { ) }\end{array}$} & levels & \multicolumn{7}{|c|}{ Ir12 } & \multicolumn{3}{|c|}{$\mathbf{2 0 1 3}$} \\
\cline { 2 - 7 } & $\begin{array}{l}\text { Continuous } \\
\text { flooding }\end{array}$ & $\begin{array}{c}\text { Irrigation } \\
\text { every 6 } \\
\text { days }\end{array}$ & $\begin{array}{c}\text { Irrigation } \\
\text { every 9 } \\
\text { days }\end{array}$ & $\begin{array}{c}\text { Continuous } \\
\text { flooding }\end{array}$ & $\begin{array}{c}\text { Irrigation } \\
\text { every 6 } \\
\text { days }\end{array}$ & $\begin{array}{c}\text { Irrigation } \\
\text { every 9 } \\
\text { days }\end{array}$ \\
\hline 0 & $5.44 \mathrm{ef}$ & $5.24 \mathrm{f}$ & $4.88 \mathrm{f}$ & $5.60 \mathrm{ef}$ & $5.31 \mathrm{fg}$ & $4.79 \mathrm{~g}$ \\
110 & $9.15 \mathrm{~b}$ & $8.71 \mathrm{~b}$ & $5.97 \mathrm{e}$ & $9.12 \mathrm{~b}$ & $8.77 \mathrm{~b}$ & $6.13 \mathrm{de}$ \\
165 & $10.43 \mathrm{a}$ & $9.96 \mathrm{a}$ & $6.68 \mathrm{~d}$ & $10.55 \mathrm{a}$ & $10.13 \mathrm{a}$ & $6.74 \mathrm{~d}$ \\
220 & $10.14 \mathrm{a}$ & $10.32 \mathrm{a}$ & $7.63 \mathrm{c}$ & $10.18 \mathrm{a}$ & $10.45 \mathrm{a}$ & $7.72 \mathrm{c}$ \\
\hline
\end{tabular}

Means: followed by the same litter (s) are not significantly different, according to DMRT. 
Table 15: Effect of the interaction between irrigation intervals and nitrogen levels on straw yield $\left(\right.$ tha $\left.^{-1}\right)$ of Giza 179 rice cultivar during 2013 and 2013 seasons.

\begin{tabular}{|c|c|c|c|c|c|c|}
\hline \multirow{3}{*}{$\begin{array}{l}\text { Nitrogen levels (kg } \\
\mathrm{Nh}^{-1} \text { ) }\end{array}$} & \multicolumn{6}{|c|}{ Irrigation intervals } \\
\hline & \multicolumn{3}{|c|}{2012} & \multicolumn{3}{|c|}{2013} \\
\hline & $\begin{array}{l}\text { Continuous } \\
\text { flooding }\end{array}$ & \begin{tabular}{|c} 
Irrigation \\
every 6 days
\end{tabular} & \begin{tabular}{|c|} 
Irrigation \\
every 9 days
\end{tabular} & $\begin{array}{l}\text { Continuous } \\
\text { flooding }\end{array}$ & \begin{tabular}{|c|} 
Irrigation \\
every 6 days
\end{tabular} & \begin{tabular}{|c|} 
Irrigation \\
every 9 days
\end{tabular} \\
\hline 0 & $7.86 \mathrm{~h}$ & $7.92 \mathrm{~h}$ & $7.39 \mathrm{~h}$ & $7.97 f$ & $8.03 f$ & $7.49 f$ \\
\hline 110 & $12.37 d$ & $12.16 \mathrm{~d}$ & 8. & 12 & $12.31 \mathrm{c}$ & $9.13 e$ \\
\hline 165 & $13.74 \mathrm{bc}$ & 13 & 9. & 13 & $13.59 b$ & $9.78 \mathrm{e}$ \\
\hline 220 & $13.98 \mathrm{~b}$ & $14.87 \mathrm{a}$ & $11.28 \mathrm{e}$ & $14.24 \mathrm{~b}$ & $15.16 \mathrm{a}$ & $11.52 d$ \\
\hline
\end{tabular}

Means: followed by the same litter (s) are not significantly different, according to DMRT.

\section{Water relations}

Data listed in Table 17 refer that irrigation intervals had marked variation in total applied water, water save\% and water use efficiency in both seasons. The continuous flooding (CF) had the highest values of total applied water, while the prolonged irrigation interval of 9 days recorded the minimum values of total applied water. The irrigation interval of 9 days gave the maximum amount of water save and the CF treatment gave the least amount of water save. The intermittent irrigation interval of 6 days clearly mediated the two irrigation treatment intervals in amount of water save. Interestingly, the highest mean of water use efficiency was obviously recorded by the irrigation interval every 6 days with slightly yield reduction. The prolonging irrigation interval every 9 days gave the highest value of yield reduction and water save\%, but it gave the lowest values of water use efficiency. Therefore, irrigation interval every 6 days could be recommended under drill seeded rice based on water use efficiency and other water relations (Tables 16 and 17).Similar data had been reported by Zayed et al. (2007)and Majid (2012).

Data in Table 18 showed that the tested nitrogen levels markedly varied in their effect of water use efficiency in both seasons. The lowest values of water use efficiency were produced by zero nitrogen level, while the highest values of water use efficiency were produced by the highest nitrogen level of $220 \mathrm{~kg} \mathrm{Nha}^{-1}$. It was observed that the combination of nitrogen level of $220 \mathrm{kgNha}^{-1}$ and irrigation interval of 6 day gave the highest values of water use efficiency in both seasons (Table 18). Furthermore, under both irrigation intervals of 6 and 9 days, increasing nitrogen level linearly increased water use efficiency up to $220 \mathrm{~kg} \mathrm{Nha}^{-1}$. At the same time, under continuous flooding the increasing water use efficiency was recorded up to only $165 \mathrm{~kg}$ $\mathrm{Nha}^{-1}$ and the water use efficiency was decreased with high nitrogen level of $220 \mathrm{kgNha}^{-1}$. Similar data was claimed by Majid(2012).

From going discussion, it could be concluded that application of nitrogen at the rate of 165 and/or $220 \mathrm{~kg} \mathrm{Nha}^{-1}$ was found to be optimum for rice growth; yield and water use efficiency as well as water save allied with 6 days irrigation intervals for drilled Giza 179 rice variety. The increasing nitrogen level up to $220 \mathrm{~kg} \mathrm{Nha}^{-1}$ showed ability to relief the undesirable effect of water shortage under prolonged irrigation interval keeping high yield and reasonable WUS as well as water save even with water stress plus the others drill-seeded rice's advantages. 
Table 16: Water use for 25 days before starting irrigation treatments $\mathrm{m}^{3}$ ha- ${ }^{1}$., water use through irrigation treatments $\mathrm{m}^{3} \mathrm{ha}^{-1}$ and total water usedm ${ }^{3}$ ha- $^{-1}$ during 2012 and 2013 seasons.

\begin{tabular}{|c|c|c|c|c|c|c|}
\hline \multirow[t]{2}{*}{ Irrigation treatments } & \multicolumn{2}{|c|}{$\begin{array}{l}\text { Water used } \\
\text { before } \\
\text { treatments }\end{array}$} & \multicolumn{2}{|c|}{$\begin{array}{c}\text { Water used } \\
\text { trough treatments } \\
\left(\mathrm{m}^{3} \mathrm{ha}^{-1}\right)\end{array}$} & \multicolumn{2}{|c|}{$\begin{array}{l}\text { Total water used } \\
\left(\mathrm{m}^{3} \mathrm{ha}^{-1}\right)\end{array}$} \\
\hline & 2012 & 2013 & 2012 & 2013 & 2012 & 2013 \\
\hline Continuous flooding (CF) & \multirow{3}{*}{2886.5} & \multirow{3}{*}{2795.8} & 9518.7 & 9424.6 & 12405.2 & 12220.4 \\
\hline Irrigation every 6 days & & & 8658.4 & 8718.3 & 11544.9 & 11514.1 \\
\hline Irrigation every 9 days & & & 7186.5 & 7041.8 & 10073.0 & 9837.6 \\
\hline
\end{tabular}

Table17:Some water relations of Giza 179 cultivar as affected by irrigation intervals under drill-seeded rice during 2012 and 2013 seasons.

\begin{tabular}{|c|c|c|c|c|c|c|c|c|c|c|}
\hline \multirow[t]{2}{*}{$\begin{array}{l}\text { Irrigation } \\
\text { treatments }\end{array}$} & \multicolumn{2}{|c|}{$\begin{array}{l}\text { Total water } \\
\left(\mathrm{m}^{3} \mathrm{ha}^{-1}\right)\end{array}$} & \multicolumn{2}{|c|}{$\begin{array}{c}\text { Grain yield } \\
\left(\text { tha }^{-1}\right)\end{array}$} & \multicolumn{2}{|c|}{$\begin{array}{c}\text { Yield } \\
\text { reduction } \\
(\%)\end{array}$} & \multicolumn{2}{|c|}{$\begin{array}{c}\text { Water saved } \\
(\%)\end{array}$} & \multicolumn{2}{|c|}{$\begin{array}{c}\text { Water use } \\
\text { efficiency } \\
\left(\text { WUE kgm }{ }^{-3}\right)\end{array}$} \\
\hline & 2012 & 2013 & 2012 & 2013 & 2012 & 2013 & 2012 & 2013 & 2012 & 2013 \\
\hline $\begin{array}{l}\text { Continuous } \\
\text { flooding (CF) }\end{array}$ & 12405.2 & 12220.4 & $8.79 a$ & $8.86 a$ & - & - & - & - & 0.709 & 0.7025 \\
\hline $\begin{array}{l}\text { Irrigation every } \\
6 \text { days }\end{array}$ & 11544.9 & 11514.1 & $8.56 a$ & 8.67a & 2.62 & 2.14 & 6.93 & 5.78 & 0.741 & 0.753 \\
\hline $\begin{array}{l}\text { Irrigation every } \\
9 \text { days }\end{array}$ & 10073.0 & 9837.6 & $6.29 b$ & $6.35 b$ & 28.44 & 28.33 & 18.80 & 19.50 & 0.624 & 0.645 \\
\hline
\end{tabular}

Table 18:Effect of the interactionbetween irrigation intervals and nitrogen levels on water use efficiency during 2012 and 2013

\begin{tabular}{|c|c|c|c|c|c|c|}
\hline \multirow[b]{2}{*}{$\begin{array}{l}\text { Nitrogen levels (kg } \\
\text { Nha }^{-1} \text { ) }\end{array}$} & \multicolumn{3}{|c|}{2012} & \multicolumn{3}{|c|}{2013} \\
\hline & $\begin{array}{l}\text { Continuous } \\
\text { flooding }\end{array}$ & $\begin{array}{c}\text { Irrigation } \\
\text { every } 6 \\
\text { days }\end{array}$ & $\begin{array}{c}\text { Irrigation } \\
\text { every } 9 \text { days }\end{array}$ & $\begin{array}{l}\text { Continuous } \\
\text { flooding }\end{array}$ & $\begin{array}{c}\text { Irrigation } \\
\text { every } 6 \text { days }\end{array}$ & $\begin{array}{c}\text { Irrigation } \\
\text { every } 9 \text { days }\end{array}$ \\
\hline Control & 0.439 & 0.454 & 0.484 & 0.458 & 0.461 & 0.487 \\
\hline 110 & 0.738 & 0.754 & 0.593 & 0.746 & 0.762 & 0.623 \\
\hline 165 & 0.841 & 0.863 & 0.663 & 0.863 & 0.880 & 0.685 \\
\hline 220 & 0.817 & 0.894 & 0.757 & 0.833 & 0.908 & 0.785 \\
\hline
\end{tabular}

\section{REFERENCE}

Ali,M. A.; J. K. Ladha; J. Rickman; J. S. Lales and M. Murshedulalam(2012). Evaluation of drill seeding patterns and nitrogen management strategies for wet and dry land rice.Bangladesh J. Agric. Res., 37(4):559-571.

Anbumozhi,V.E.;E. Yamaji and T. Tabuchi(1998). Rice crop growth and yield as influenced by change in pending water depth, water regime and fertilization levels. Agric. and Water Management J., 37: 241-253.

Bakker, R.R.; M. A. Bell and J.F. Rickman(2002).Mechanization issues in tillage and crop establishment for dry direct-seeded rice. In: Pandey, S., M. Motimar, L. Wade, T.P. Toung, K. Lopez and B. Hardy (ed.) 2002. Direct seeding: research issues and opportunities. Proceedings of the International Workshop on Direct Seeding in Asian Rice Systems: Strategic Issues and Opportunities, 25-28 January 2000, Bangkok, Thailand. Los Baños, (Philippines): International Rice Research Institute. 219 P. 
Black,C.A.;D.D. Evan; L.E.Ensminger, J.L.White and F.E.Clark(1965). Methods of soil analysis(chemical and microbiology properties,part2).Amer.Soc. of Agron.

Duncan,B.D.(1955).Multiple range and multiple $\mathrm{F}$ tests. Biometrics,11:1-42.

El-Ekhtyar, A.M.(2004).Behavior of some rice cultivars as affected by drought treatments under drill seeded rice. Ph.DThesis, Agron. Dept., Fac. of Agric. Mansoura Univ.

El-Habat, Howida, B.I.; E.S.Naeem;T.M.Abdel-Megeed and A.M.ElEkhtyar(2013).Rice seed rates and nitrogen levels effects on growth and yield of Egyptian hybrid rice1 under drill seeded method. J Agric.Res.Kafr El-sheikh Univ., 39(2):210-230.

El-Kholy, M.H.; M.H. Hegazy and F.K. Abdel Fatah(1999). Response of rice yield to $\mathrm{N}$ fertilizer, bio-inoculation and herbicides application. J. Agric. Sci. Mansoura Univ., 24(1):5165-5173.

El-Refaee, I.S.;M.E.Mosalem and F.A.Sorour(2005).Effect of irrigation regimes on productivity of Giza 178 and Sakha 102 rice cultivars under broadcasted methods. Egypt.J.Agric. Res.,83(5B):377-391.

El-Refaee, I.S.; A.M.EL-Ekhtyar and A.A. El-Gohary(2008).Improving rice productivity under irrigation intervals and nitrogen fertilizer. Proceedings( the Second Field Crop Conference), FCRI, ARC, Giza, Egypt,14-16Oct,333-347.

Farooq, M.;A. Wahid.;D.J.Lee; O.Ito and K.H.M.Siddique(2009).Advances in drought resistance of rice. Crit. Rev. Plant Sci., 28:199-217.

Farooq, M.; H.M. Kadambot;H.Siddique, C.Rehman; T.Aziza;D.J.Leed and A.Wahid (2011).Rice direct seeding :Experience, challenges and opportunities.Soil \& Tillage Research, 111 (2): 87-98.

Ho, Nai-Kin and Z. Romli(2002). Impact of direct seeding on rice cultivation: lessons from the Muda area of Malaysia. In: Pandey, S., M. Motimar, L. Wade, T.P. Toung, K. Lopez and B. Hardy (ed.) 2002. Direct seeding: research issues and opportunities. Proceedings of the International Workshop on Direct Seeding in Asian Rice Systems: Strategic Issues and Opportunities, 25-28 January 2000, Bangkok, Thailand. Los Baños, (Philippines): International Rice Research Institute. 383 P.

Gomez, K.A. and A.A. Gomez(1984). Statistical procedures for agricultural research $.2^{\text {nd }}$ ed., John Wiley and Sons, USA.

Khafaga,E.E.E.; M.I.Abdel-kalek and H.A.A.Awad(2006). Irrigation water depth and nitrogen fertilizer levels for rice production under two water table.J. AgricSci Mansoura Univ;31(6):4041-4047.

Ladha, J. K.; H. P. Pathak; T. J. Krupnik; J. Six and C.VanKessel (2005). Efficiency of fertilizer nitrogen in cereal production: retrospect and prospect. Advances in Agronomy, 87: 86

Majid, A.(2012). The Effect of water saving irrigation and nitrogen fertilizer on rice production in paddy fields of Iran. International Journal of Bioscience, Biochemistry and Bioinformatics, 2(1):56-59.

Michael, A.M. (1978). Irrigation theory and practices. Vikas Publishing House PUTLTD New Delhi, Bombay.

Tabbal,D.F.;B.A.M.Bourman;S.I.Bhuiyan, E.B.Sibayan and M.A.Sattar(2002). On farm strategies for reducing water input in irrigated rice: Case studies in the Philippines. Agric. Water Management, 56(2):93-112. 


\section{El-Ekhtyar A.M.}

Yang, X. and X.Sun (1992). Physiological mechanism of varietal differences in rice plant response to low N level .Acta Pedol.Sin.,29:73-79.

Yoshida, S.; D.A. Forno ; J.H. Cock ; and K.A.Gomez ( 1972). Laboratory manual for physiology studies of rice .IRRI, Los Banos, Philippines.

Zayed, B. A.; A.M.El-Ekhtyar;A.B.El-Abd and M.A. Badawi (2006).Response of hybrid and inbred rice varieties to various nitrogen levels under saline soil conditions .J.Agric.Sci. Mansoura Univ.,31(12):7497-7509.

Zayed, B.A.;S.M. Shehata; W.M. Elkhoby and E.E.E.Kafaga (2007).Rice and water productivity as affected by irrigation intervals and potassium splitting under newly reclaimed saline soil.J. Agric. Res. Kafr El- Sheikh Univ.,33(4):807-823.

\footnotetext{
تاثثير فترات الري و معدلات النتروجين علي إنتاجية المياة ، نمو و محصول الأرز للصنف

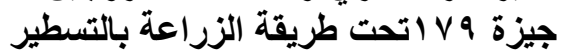
احمد محمد محمد الأختيار.

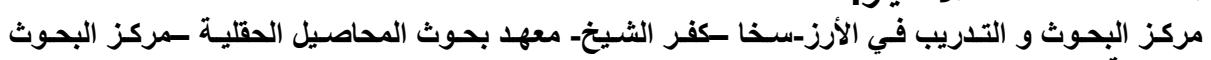

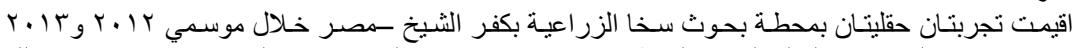
الزراعية_مصر.

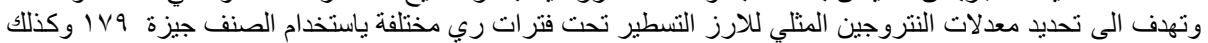

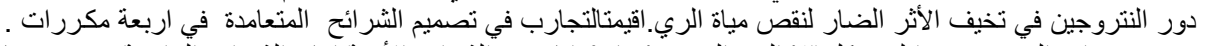

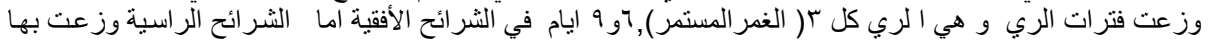

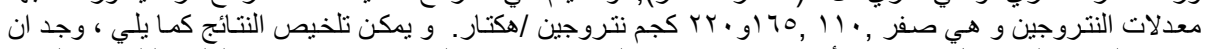

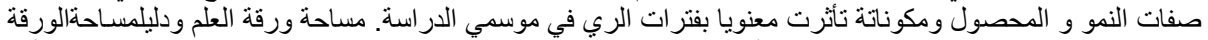

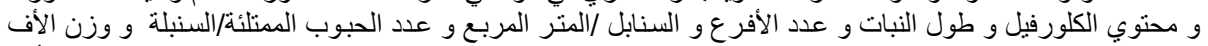

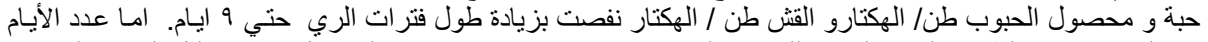

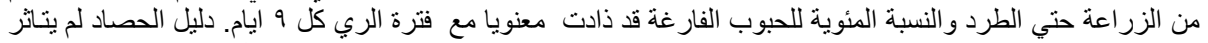

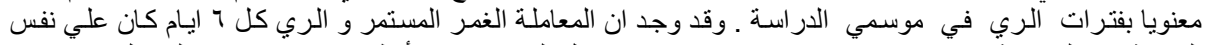

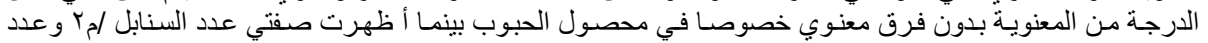

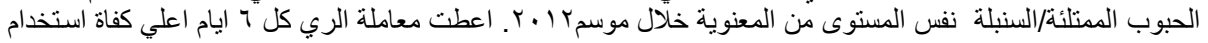

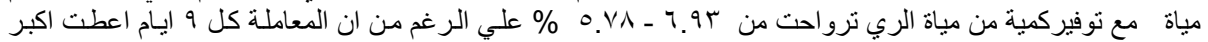

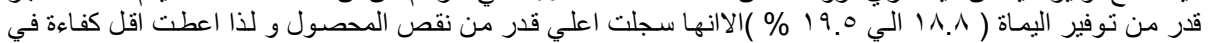

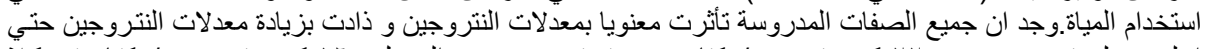

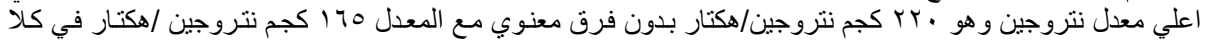

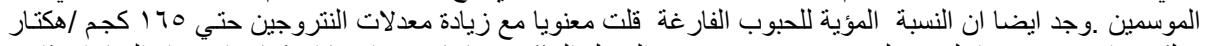

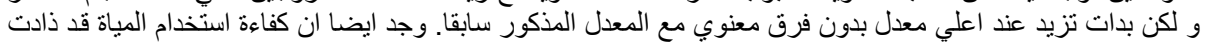

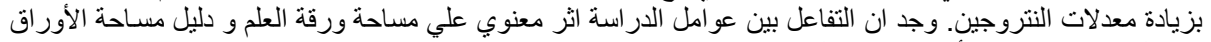

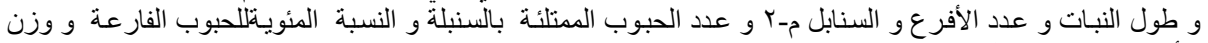

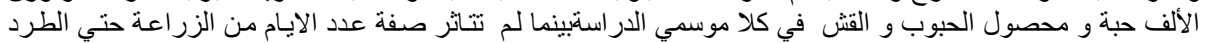

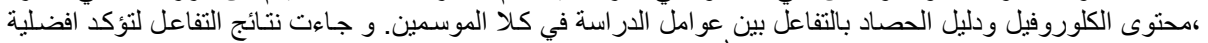

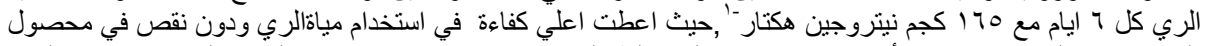

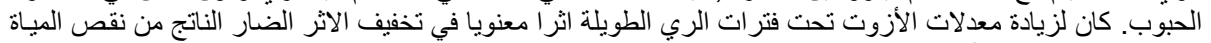

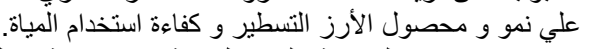

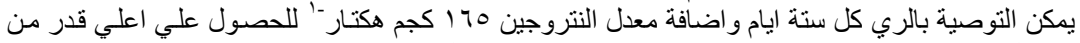

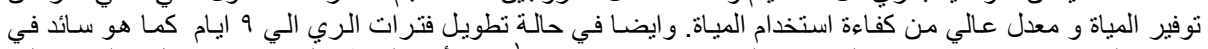

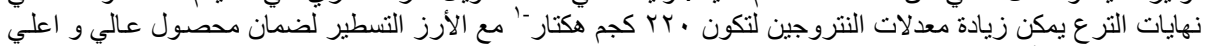
عائد من وحدة الأرض و الترن زيادة
} 